\title{
Rapport Management in Intercultural Interaction-A Case Study on Emails
}

\author{
Wu Jihong ${ }^{1 *}$, Huang Ziqing ${ }^{2}$, Liu Min ${ }^{3}$ \\ ${ }^{1}$ Ph.D., professor, School of English for International Business, Guangdong University of Foreign Studies. \\ ${ }^{2}$ Postgraduate student, School of English for International Business, Guangdong University of Foreign Studies. \\ ${ }^{3}$ Postgraduate student, School of English for International Business, Guangdong University of Foreign Studies.
}

*Corresponding Author: 1Wu Jihong,Ph.D., professor, School of English for International Business, Guangdong University of Foreign Studies.

\begin{abstract}
Communication involves both information exchange and relationship building. Based on studies on politeness and face, Spencer-Oatey puts forward the rapport management theory, which has been widely used in research on intercultural communication, pragmatics and intercultural business communication. This paper applies genre analysis to the email discourses collected and explores, within the theoretical framework of rapport management, the impact of contextual, social and individual factors on rapport management as well as the use of rapport management strategy in intercultural communication. The research shows that in intercultural interaction, participants have to develop a keen awareness of both contextual factors, including interaction goals and the nature of the communicative activity, and social factors, including participant relations, role rights and obligations, and face sensitivity. More importantly, individual factors should be given due consideration, including emotion regulation and stylistic flexibility competence. It's hoped that the research may enable us to gain a more comprehensive understanding of the factors that influence people's dynamic judgment or rapport, which is essential to understanding the problems that occur in intercultural interaction and to approaching these problems with efficient rapport management skills..
\end{abstract}

Keywords: rapport management; intercultural communication; face sensitivity; rights and obligations; email; linguistic options.

\section{INTRODUCTION}

The purposes for communication consist of both information exchange and rapport management. "In most cases, no matter it is constative or performative, the information exchange process is always accompanied by rapport management. Therefore, the two purposes for communication are interwoven and interdependent" (Ran, 2012: 1). So language, as the main channel for communication, serves the dual functions of information exchange as well as rapport management.

Linguistics research on language functions in interpersonal communication mainly includes (im)politeness, face management and rapport management (Fraser \& Nolan, 1981; Leech, 1983; Brown \& Levinson, 1987; Kasper, 1996; Watts, 2003; Culpeper, 2009; Spencer-Oatey, 2000). In recent years Spencer-Oatey's rapport management theory, which evolves from previous research, has attracted attention worldwide and has been widely used in studies on linguistics, intercultural communication and interpersonal pragmatics. This paper, with genre analysis on request and responding emails, explores the use of rapport management strategies in intercultural communication and the impact of different cultures on rapport management.

\section{RAPPORT MANAGEMENT THEORY}

Spencer-Oatey reckons that research on politeness and face, with a great emphasis on individuality and the harmony (rapport) of interpersonal relationship, ignores the social impact on face. Rapport is a subjective perception of harmony or disharmony, smoothness-turbulence and warmth-antagonism in the course of interpersonal communication, and this perception is dynamic and easily affected by the society (Spencer-Oatey\& Franklin, 2009). Thus, to explore the formation of harmonious or disharmonious relationship, Spencer-Oatey proposes rapport management theory, which aims to examine especially "the use of language to promote, maintain or threaten harmonious social relations" 
from sociopragmaticperspective(Spencer-Oatey, 2000: 3). Given that rapport management theory covers both personal and social, subjective and objective perspectives in the research on harmony and disharmony, it's believed that compared with Brown and Levinson's face theory and Leech's interpersonal rhetoric theory, Spencer-Oatey's model is "an interpersonal rhetorical model with universal explanatory capacity" (Ran, 2012: 5).

The rapport management theory mainly includes the following:

\subsection{Rapport-Management Strategies}

Rapport-management strategies cover a wide range of linguistic options which can be used for the management of face and sociality rights, and hence for rapport management (Spencer-Oatey, 2000).

Spencer-Oatey $(2000,2002,2008)$ proposes that rapport management includes face management and sociality rights management. The former refers to the quality face which is related to individuals and social identity face while the latter refers to the equity rights and association rights in interpersonal communication. Therefore, rapport management theory includes both personal perspective and social perspective, usually involving face management, sociality rights, obligations and interactional goals, etc. Spencer-Oatey (2000) believes that every language provides a very wide range of linguistic options that can be used for managing face and sociality rights, and they permeate every domain of the rapport management, including speech acts, discourse content and structure, behavioral participation, stylistic use, paralanguage and non-verbal language.

Factors affecting the choice on rapport management strategies include rapport orientation, contextual variables and pragmatic conventions. Rapport orientation refers to the desire to enhance, maintain, neglect or challenge the harmonious relationship. Contextual variables contain four important factors, such as participant relation, message content, rights and obligations as well as communicative activity. Pragmatic conventions involve sociopragmatic conventions (e.g. Leech's tact maim for politeness) and pragmalinguistic conventions such as the convention on topic choices. In intercultural communication, factors affecting rapport management relate to "contextual assessment norms (e.g. differing assessments and expectations on role relationship, such as teacher-student or employeremployee), sociopragmatic conventions, pragmalinguistic conventions, fundamental cultural values and inventory of rapport-management strategies (e.g. honorific forms in Japanese which are absent in European languages)" (ibid., 45).

\subsection{Rapport-Threatening Acts}

Rapport-threatening acts are the illocutionary acts that inherently threaten the face needs of the interlocutors.

Interpersonal rapport is significantly affected by behavioral expectations, face sensitivities and interactional needs. Behavioral expectations depend on the norms and standards of speech acts, behavioral participation, choices of genre and non-language acts. Meanwhile, equity and association rights also exert influences on behavioral expectations. Face sensitivities involves identity face and respectability face as well as individual and group face. Interactional needs are subject to interlocutors' interactional purposes and goals. The three factors are interwoven, jointly contributing to interlocutors' perception on face, politeness and interactional purpose during the whole process of rapport management. In view of this, Spencer-Oatey proposes that factors threatening rapport include face-threatening right-threatening, goal-threatening behaviors and obligation negligence. Different from Brown and Levinson, who developed face-threatening theory from speech act theory, SpencerOatey holds that all language use (request, order, criticism, etc.) is bound to affect rapport because it affects people's judgments on face, rights, obligations and interactional goals.

\subsection{Rapport Management Competencies}

The essence of rapport management theory is Spencer-Oatey's interpretation on interpersonal rapport management competencies, which comprises contextual awareness, interpersonal attentiveness, social information gathering, social attuning, emotion regulation and stylistic flexibility (see Table 1).

Table1. Rapport management competencies (Spencer-Oatey\& Franklin: 2009)

\begin{tabular}{|l|l|}
\hline $\begin{array}{l}\text { Contextual } \\
\text { awareness }\end{array}$ & $\begin{array}{l}\text { Sensitive to key features of the interaction, including participant relations } \\
\text { (equality/inequality and distance/closeness), role rights and obligations, and the nature of } \\
\text { the communicative activity. }\end{array}$ \\
\hline
\end{tabular}




\begin{tabular}{|l|l|}
\hline $\begin{array}{l}\text { Interpersonal } \\
\text { attentiveness }\end{array}$ & $\begin{array}{l}\text { Pays focused attention to people's face sensitivities (e.g., their status, competence, social } \\
\text { identity), behavioral expectations and interactional goals, and manage them effectively. }\end{array}$ \\
\hline $\begin{array}{l}\text { Social } \\
\text { information } \\
\text { gathering }\end{array}$ & $\begin{array}{l}\text { Gathers information about the interactional context (e.g., people's roles and positions in a } \\
\text { hierarchy) by asking relevant others or by careful observation. }\end{array}$ \\
\hline Social attuning & $\begin{array}{l}\text { Uses indirect signals such as paralanguage (e.g., intonation, speaking volume and speed, } \\
\text { pausing) and non-verbal communication (e.g., eye contact and other elements of body } \\
\text { language) to infer social meaning. }\end{array}$ \\
\hline $\begin{array}{l}\text { Emotion } \\
\text { regulation }\end{array}$ & $\begin{array}{l}\text { Able to handle criticism or embarrassment when things go wrong. Accepts and feels at } \\
\text { ease with people who are different (e.g., who hold different views or values). }\end{array}$ \\
\hline $\begin{array}{l}\text { Stylistic } \\
\text { flexibility }\end{array}$ & $\begin{array}{l}\text { Uses a range of strategies flexibly so that they are congruent with people's rapport } \\
\text { sensitivities. }\end{array}$ \\
\hline
\end{tabular}

\subsection{Cultural Influence on Rapport Management Strategies}

Spencer-Oatey (2000) defines culture as a fuzzy set of attitudes, beliefs, behavioral conventions, and basic assumptions and values that are shared by a group of people, and that influence each member's behavior and interpretations of the meaning of other people's behavior. As members from different groups differ in their perception on the behavior of people from other groups, they behave in different ways. All these different groupings, such as ethnic groups, national groups, professional groups, can be seen as different cultural groups with cultural patterns.

In communication, differences among various cultural groups contribute to the variations in their language use and has "a major impact on people's assessments of appropriate language use, and hence rapport-management outcomes" (ibid., 41). Table 2 elaborates upon the point that culture may have an impact on different conventions and principles underlying language use, thus influencing the choice of rapport management strategies.

Table2. The salient aspects in terms of which cultural differences affect language use (Spencer-Oatey, 2000)

\begin{tabular}{|l|l|}
\hline Aspects & Example \\
\hline $\begin{array}{l}\text { Contextual assessment } \\
\text { norms }\end{array}$ & $\begin{array}{l}\text { When assessing the teacher-student relationship, cultural groups may have } \\
\text { differing perceptions and expectations concerning the degree of power and } \\
\text { distance, rights and obligations which are related to the role relationship. }\end{array}$ \\
\hline $\begin{array}{l}\text { Sociopragmatic } \\
\text { conventions }\end{array}$ & $\begin{array}{l}\text { In interaction, some societies value overt expressions of modesty while others } \\
\text { prefer more "honest" evaluation. }\end{array}$ \\
\hline $\begin{array}{l}\text { Pragmalinguistic } \\
\text { conventions }\end{array}$ & $\begin{array}{l}\text { When an apology is recognized as necessary in a certain situation, members } \\
\text { from one cultural group may deliberately include an additional explanation for } \\
\text { the fault, while members from the other group may merely use } \\
\text { acknowledgement of fault. }\end{array}$ \\
\hline
\end{tabular}

\section{RESEARCH METHOD}

\subsection{Data Collection}

The corpus of the study consists of the emails between Li Hong (hereafter Li), a Chinese academic visitor; Susan, the personnel secretary of the college; and Ellen House, Li's tutor during her academic visit to a university in the United Kingdom. It is worth mentioning that in Susan and Ellen's emails, apart from their signatures, their titles, location for workplace, email address and telephone numbers are included as conventional format for institutions. They are excluded in the following sample presentation which includes Li's two request emails and four responding emails from Susan and Ellen. A total of 15 emails on this matter were collected, all of which contain complete framing moves including subject, address, salutation and signature.

\subsection{Research Method and Research Questions}

Since Li had to submit a visit report with the tutor's evaluation to the Chinese Embassy before the end of the academic trip, Li sent emails to Susan and Ellen for the evaluation. So primarily, these emails belong to the category of request and responding. Request is regarded as one of the rapport sensitive speech acts in Spencer-Oatey's (2008) rapport management theory. As a typical speech act, the request made by the speaker is likely to be face-threatening for the hearer who may receive a sense of challenge on his or her authority, status or self. Thus the speaker tends to employ different communicative strategies to ease the sense of challenge held by the hearer. Similarly, refusal, violating the politeness maxims, also shows potential to threat interlocutor's face, triggering conflicts in interpersonal communication. Therefore, linguistic strategies are often adopted to mitigate the 
threat caused by refusal when responding to request (Beebe et al., 1990; Felix-Brasdefer, 2004).

As a genre, email is brief, easily understood and straightforward with shorter sentences than traditional communication forms. It resembles features of both spoken and written language with a mix of stylistic formality and informality (Bjorge, 2007; Jensen, 2009). According to genre analysis, email usually has two moves, framing move and content move. The former includes the stylized components of an email (e.g. subject, opening and closing) while the latter refers to the main content. In discourse analysis, people usually employ move structure analysis to divide the text structure into different moves and steps, deeply probing into the organization of the discourse in order to excavate the social function and communicative purpose of the discourse (Swales, 1990). Hence, with genre analysis, people not only try to describe linguistic features in a text, but also further explore the role sociocultural and cognitive factors play in the construction of a text.

In this case, the author will base the study on rapport management theory, coupled with genre and speech act analysis, exploring the use of rapport management strategies, linguistic strategies and pragmatic strategies in the emails, which mainly reside in the category of request and responding. The author will focus on content moves and primarily elaborates the speech act strategies adopted in the illocutionary domain.

The study aims to answer the three questions below.

1.What rapport management strategies are adopted by the interlocutors?

2.What are the factors that affect the use of rapport management strategies?

3.How do cultural differences affect the use of rapport management strategies?

\section{Data PRESEnTAtion AND Discussion}

A week before the request email was sent to Susan, Li met Ellen by chance and orally asked Ellen to make a written evaluation reporting Li's performance during the academic trip. However, Ellen held that she was not obliged to provide an evaluation because this was the requirement from Chinese embassy, not from the University. Li tried to demonstrate that the evaluation was an indispensable part in the visiting program and offered to make a draft herself, and Ellen eventually agreed to sign the evaluation.

Two weeks later, Li sent Susan an email with the draft and asked her to forward it to Ellen, who was made to feel irritated, and then an exchange of emails followed the incident.

\subsection{Data Presentation}

Address is one of the main factors that reflect the distance between the interlocutors and affect the evaluation of politeness. "In British, there is an increasing move towards informality (for example, in the use of terms of address and the conduct of meetings), and an implicit assumption that everyone finds informality more comfortable than formality" (Spencer-Oatey\& Xing, 2000: 284). The corpus in this study shows that most emails start with "dear/ hi + surname/name", which is in line with the findings of previous research.

(1) Sample 1

Hi Susan

How are you? I'm going to return to China on 30 June, and before I go I will have to fill in some forms. Could you help me with the certificate (with telephone number. fax and email address)? I have attached a sample for your reference. Moreover, Ellen's signature is wanted for the tutor's evaluation in my report. I've talked about it with her.

$\mathrm{Li}$

In Sample 1, Li first extended the wish to establish rapport by greeting in the very beginning, and then adopted indirect request strategies such as modal verbs, passive voice and other linguistic strategies to ease the possible threat imposed on the face and right of the email recipient. At the same time, Li also provided a draft of tutor's evaluation which was intended to save the trouble for Ellen. Finally, Li emphasized the rationality and necessity of tutor's evaluation in her report for the Chinese Embassy when she finished the academic trip.

(2) Sample 2 
$\mathrm{Hi} \mathrm{Li}$

I'm well, thank you.

Although I will issue this letter via email, I'm a little puzzled as to how you acquired a reference from Ellen when she has no recollection of providing you with one. If you have written the reference yourself, I must inform you that this is considered fraudulent to impersonate a member of staff to complete your report.

If you require an official signature from Ellen, please leave the report in the box outside her office (65/3001) and she will sign it tomorrow afternoon.

Susan

In sample 2, Susan first responded to Li's greetings and expressed her thanks, which was in line with sociopragmatic norms. Although Susan did not directly reject Li's request, it could be inferred that it was most likely that Ellen had forgotten the conversation with Li two weeks ago. So she posed a very serious charge of fraudulence against Li, which led to some disharmony. It was obvious that Li's request was deemed as offensive to Ellen's identity. Thus the potential conflicts arose. Nevertheless, Susan responded to Li's request by offering an alternative, and to a certain extent, Li achieved the interactional goal though she failed in rapport management as apparently because a strong negative mood could be detected in Susan's email. As a remedy, Li sent an email to Ellen to refresh her memory of the previous oral agreement with a reminder of specific time, places and the names of the people who were present, and meanwhile, this email was sent to Susan (this email is not included in the corpus as it's comparatively irrelevant). However, Li's email failed to reach Ellen because, before Li's email was sent, Ellen had told Susan (see sample 3) that she would no longer accept Li's email. As a response, Susan sent an email (see sample 3), breaking rapport.

(3) Sample 3

$\mathrm{Hi} \mathrm{Li}$

I have spoken with Ellen and although she does not agree with your account of the communication between you and her, she will approve the report nonetheless. Please be advised that Prof. House does not expect any more requests from you in your remaining time here or when you return to China and you may not receive a response should you wish to contact her.

Many thanks.

Susan

In sample 3, as a substitute for a blunt statement "she thinks you are lying", which was a serious charge, Susan chose an euphemistic expression "she does not agree" as she may have been fully aware of the threat imposed on Li's face. Meanwhile, when conveying Ellen's message, Susan chose a very formal style in the email and referred to Ellen as Prof. House, which undoubtedly created a sense of alienation between the interlocutors, challenging and even impairing the rapport management. Worse still, "many thanks" in the end of this email, which is not a conventional strategy for accepting requests, was by no means sincere as "any unexpected use is strategic" (Spencer-Oatey\& Xing, 2000: 286). It's proposed that "no sentence is inherently polite or impolite. We often take certain expressions to be impolite, but it is not the expressions themselves but the conditions under which they are used that determines the judgment of politeness...... Whether or not an utterance is heard as being polite is totally in the hands (or ears) of the hearer" (Fraser \& Nolan, 1981: 96). Therefore, "many thanks", as an unexpected interactional strategy, implied that "if you stop sending emails to Ellen, we will be grateful", which further aggravated the situation.

(4) Sample 4

$\mathrm{Hi} \mathrm{Li}$

The letter you wanted me to sign is waiting for you in the box outside my office.

I'm afraid I have no recollection of talking with you at the 3 minute thesis presentation. I was there to see my student competing, and was very busy with that. If you wanted me to sign something for you, it would have been better to email and ask me. I have far too much to do (including 26 PhD students who I currently supervise) to be able to remember inconsequential quick chats with visiting scholars when I'm in the middle of doing something else.

I hope your stay here has been useful. 
Ellen

As Ellen had extended her wish not to receive any emails from $\mathrm{Li}, \mathrm{Li}$ put the evaluation report to be signed in Ellen's office mailbox with a note explaining the misunderstanding. In the following day, Li received an email from Ellen (sample 4), which signals a turning point in rapport management. In the email, Ellen first gave a positive response to Li's request, and then explained her behavioral expectation from $\mathrm{Li}$, and finally expressed her good wishes for $\mathrm{Li}$, from which her willingness to mitigate the conflicts and maintain rapport could be detected. It seemed that the communication was successful as Li was granted the signature on the report, yet from interpersonal perspective, it was a failure as Ellen still declined the oral agreement with $\mathrm{Li}$, who responded with an email to Susan (see sample 5).

(5) Sample 5

Hi Ellen

Thank you for your email and your signed name. I think I have to make it clear that I'm absolutely sure that I talked with you about the report at 3-min presentation: I was sitting in front of you and you were sitting with some of your students, and one of them was Nancy, whom I know. I feel sorry if you don't remember. Actually I did send you an email and an attachment of my report on 1 June, 2015, 11:38 (I've showed you an copy with my report), but unfortunately it was rejected and I didn't check my email till this morning. I feel sorry for that if it makes you feel any imposition. The only thing I have in my mind is to save you as much trouble as I can.

If I have done anything that makes you upset, please accept my sincere apology, but I surely want you and Susan to know that I'm not lying about anything.

$\mathrm{Li}$

In sample 5, Li first expressed her gratitude to Ellen for her email and then she re-stressed her honesty by recollecting the details when the verbal agreement had been made, including time, place and people involved. At the same time, Li clarified that her initial intention was by no means to impose any obligation, but to save time and trouble for Ellen, a cost-benefit consideration from Ellen's perspective. It's worth noting that a lot of lexical and syntactic mitigators were employed in Sample 5 to reduce the possible threat on Ellen's identity, face, and rights, and on the other hand, Li chose some boosters for the real purpose of communication, that was, to defend and affirm her integrity and honesty.

(6) Sample 6

$\mathrm{Hi} \mathrm{Li}$,

Not to worry, there has clearly been a misunderstanding.

Susan

Sample 6 was a reply from Susan (sample 5), in which she adopted a less formal style, one of the strategies affecting interpersonal relationship management, and a more relaxing atmosphere was created. In the email, Susan chose an imperative sentence and the booster "clearly" to stress that it was a misunderstanding. To $\mathrm{Li}$, it was a sign that the misunderstanding was cleared and the communication ended as a success not only from functional perspective, but also from interpersonal perspective.

\subsection{Pragmatic Strategies Employed in Emails}

The corpus shows that Li primarily used direct, indirect and unconventionally indirect strategies for requests (see Table 3), while Susan and Ellen employed both explicit and implicit response strategies, including positive and explicit responses to request, but negative and implicit responses to rapport management (see Table 4). Nevertheless, they all used lexical and syntactical mitigators and boosters to alleviate the threat posed on face in interpersonal conflicts (see table 5).

Table3. Li's request strategies in the emails

\begin{tabular}{|l|l|l|}
\hline direct vs indirect & $\begin{array}{l}\text { request } \\
\text { strategies }\end{array}$ & example \\
\hline \multirow{2}{*}{ direct } & want statements & $\begin{array}{l}\text { I surely want you and Susan to know that I'm not lying about } \\
\text { anything. }\end{array}$ \\
\cline { 2 - 3 } & need & I have to fill in some forms \\
\hline
\end{tabular}


Rapport Management in Intercultural Interaction-A Case Study on Emails

\begin{tabular}{|l|l|l|}
\hline & statements & \\
\hline $\begin{array}{l}\text { conventionally } \\
\text { indirect }\end{array}$ & $\begin{array}{l}\text { query } \\
\text { preparatory }\end{array}$ & Could you help me with the certificate \\
\hline $\begin{array}{l}\text { unconventionally } \\
\text { indirect }\end{array}$ & hints & $\begin{array}{l}\text { I'm going to return to China in 30 July } \\
\text { I've talked about it with her } \\
\text { I have attached a sample for your reference }\end{array}$ \\
\hline
\end{tabular}

Table4. Susan's and Ellen's responding strategies in the emails

\begin{tabular}{|l|l|l|}
\hline $\begin{array}{l}\text { explict } \\
\text { vs } \\
\text { implict }\end{array}$ & $\begin{array}{l}\text { response } \\
\text { strategies }\end{array}$ & example \\
\hline explicit & $\begin{array}{l}\text { request } \\
\text { acceptance }\end{array}$ & $\begin{array}{l}\text { I will issue this letter via email } \\
\text { she will approve the report nonetheless } \\
\text { The letter you wanted me to sign is waiting for you }\end{array}$ \\
\hline \multirow{3}{*}{ implicit } & replacement & $\begin{array}{l}\text { If you require an official signature from Ellen, please leave the report in } \\
\text { the box outside her office }\end{array}$ \\
\cline { 2 - 3 } & $\begin{array}{l}\text { outcome } \\
\text { statement }\end{array}$ & $\begin{array}{l}\text { If you have written the reference yourself, I must inform you that this is } \\
\text { considered fraudulent to impersonate a member of staff to complete your } \\
\text { report. }\end{array}$ \\
\cline { 2 - 3 } & suspicion & $\begin{array}{l}\text { I'm a little puzzled, she does not agree with your account } \\
\text { I have no recollection of talking with you }\end{array}$ \\
\cline { 2 - 3 } & criticism & $\begin{array}{l}\text { If you wanted me to sign something for you, it would have been better to } \\
\text { email and ask me }\end{array}$ \\
\hline
\end{tabular}

\subsection{Factors Affecting Choices of Pragmatic Strategies}

In intercultural communications, politeness is not an inherent attribute of discourse or language, but subject to the judgment of interlocutors, which is primarily affected by cultural differences in specific contexts, and in turn, exerts a great impacton rapport management. "Cultural differences in language use can have a major impact on people's assessments of appropriate language use, and hence rapportmanagement outcomes" (Spencer-Oatey, 2000: 41).

Table5. Syntactic and lexical features

\begin{tabular}{|c|c|l|}
\hline features & strategies & example \\
\hline \multirow{2}{*}{$\begin{array}{c}\text { syntactic } \\
\text { mitigation }\end{array}$} & subjunctive mood & $\begin{array}{l}\text { If you wanted me to sign something for you, it would have been better } \\
\text { to email and ask me (Ellen) } \\
\text { Should you...... }\end{array}$ \\
\cline { 2 - 3 } & past & Could you help me with the certificate \\
\cline { 2 - 3 } lexical & passive voice & Ellen's signature is wanted .......be advised \\
\hline mitigation & mitigators & $\begin{array}{l}\text { I think, please } \\
\text { I'm afraid, I hope may(Susan) }\end{array}$ \\
\cline { 2 - 3 } & euphemism & She does not agree with your account \\
\cline { 2 - 3 } & hedge & a little, nonetheless \\
\hline booster & booster & absolutely, surely, actually clearly \\
\hline
\end{tabular}

In the following, the author will elaborate how cultural differences, permeated in contextual and individual factors, affect rapport management in this case.

\subsubsection{Contextual Factors}

Research on pragmatics has demonstrated that a range of contextual factors have an impact on people's behavior and their use of language, which in turn influence rapport management, and participant relations, role rights and obligations, and the nature of the communicative activity, are the most prominent ones among them (Spencer-Oatey\& Franklin, 2009).

\section{(1)Interactional Goal}

People communicate either to convey information or to maintain interpersonal relationships, and in most cases the two are interwoven. In intercultural communication, it is imperative that the interlocutor should consider and coordinate both his/her and the other interlocutors' goal as "effective rapport management requires people to consider their interlocutors' face sensitivities and behavioral expectations, and the extent to which those needs are being considered and met" (Spencer-Oatey, 2005: 338). In Li's case, her upward request, which may be considered as a threat to rapport even though she tried to minimize the threat with mitigators, would most likely cause the infringement on 
Ellen's rights. On the other hand, though Ellen eventually gave a positive response to Li's request, her suspicion on Li's integrity challenged rapport even though Susan and Ellen used euphemism and mitigators to alleviate the threat on Li's face. To defend her integrity, Li employed boosters like "absolutely" and "surely" in her responding email for an emphasis. Obviously, different interactional goals determine the choices of rapport management strategies.

\section{(2) Communication Channel}

"In addition to our verbal language, we are constantly communicating our real feelings in the language of behavior"(Hall, 1990: IX). But most of the time, people from different cultures may interpret the language of behavior in a different way. In addition to verbal language, we often use nonverbal expressions and paralanguage to communicate. However, unlike face-to-face communication, when people communicate with emails, they filter out paralanguage and non-verbal expressions which prohibit people from making a precise judgment on senders' emotions and intentions and may have a negative impact on rapport management. On the other hand, emailing makes it impossible for interlocutors to express themselves by the tone, volume, and speed of speech, neither will it be possible to have eye contact and any other emotional signals, which may have a positive effect on rapport management as it will be more likely for people to ponder over words and control emotions more effectively when conflicts arise. In this case, Li communicated with Susan or Ellen in English, which put her, a Chinese, in a disadvantageous position. However, when they communicated with emails, it was possible for Li to express herself appropriately in English and choose proper pragmatic strategies to achieve her interactional goal. By avoiding the misunderstanding led by the misconduct of language (including body language) that often occurs in face-to-face communication, emailing actually contributes to rapport management in this case.

\subsubsection{Social Factors}

\section{(1) Participant Relations}

Participant relations, which have a profound impact on behavioral expectations as well as sensitivity of face, rights and obligations in rapport management, are usually subject to power and distancecloseness. Power is especially operationalized when it comes to unequal role relations, such as teacher-student and employer-employee relationship. However, "distance-closeness is operationalized in more variable ways, but typically, it includes one or more of the following: length of acquaintance, degree of familiarity, sense of like-mindedness, frequency of contact, positive/negative affect and social similarity/difference" (Spencer-Oatey\& Franklin, 2009: 106). In this case, the relation between $\mathrm{Li}$ and Ellen is the typical unequal teacher-student relation as the tutor is the one with greater control and power which affect perception of face. So upward request from the academic visitor may possibly impose an offense on Ellen, damaging rapport management. What's more, the distance between Li and Ellen exerts a negative impact on rapport management as Li only has a six-month stay in UK and they only met occasionally in campus, which makes a close relationship nearly impossible.

\section{(2) Role Rights and Obligations}

Different cultures set their own codes of conduct for different roles, which specify the rights and obligations of role members, including teachers and students. Equity and association are two fundamental principles that underlie role expectations. Equity refers to the right to be treated fairly, that is, not to be unduly imposed upon, not to be unfairly ordered about, and not to be taken advantage of or exploited (ibid.). There are two components to equity entitlement, namely cost-benefit and autonomy-imposition. Association refers to the right of people to be entitled to social involvement with others, and interactional involvement-detachment and affective involvement-detachment are the two factors to measure association (ibid.).

In this study, as required by Chinese embassy, the tutor's evaluation in the report of academic visitor is a conventionally imperative. However, it was rejected by Ellen, the tutor, who did not accept writing the evaluation as her obligation. In addition, out of the consideration of saving cost, be it of time of trouble, Li made a draft of an evaluation, which is conventionally acceptable in Chinese background, but was deemed as a threat on Ellen's equity and association rights by impairing her autonomy from Ellen's perspective. On the other hand, when Susan informed Li that Ellen would no longer receive Li's email, it triggered backlash from $\mathrm{Li}$, who was more sensitive to association right as it was undoubtedly an act of negligence as well as an infringement of Li's association right before the 
end of the Li's academic trip, exerting a negative impact on rapport. It is clear that different cultural backgrounds lead to different behavioral expectations, and once those who are expected to fulfill them fail, people who assume that they have the right to expect will feel offended, resulting in an impairment of the relationship (ibid.).

\section{(3) Face Sensitivity}

Face, the core factor in interpersonal communication, is closely related to one's perception of selfidentity, including individual identity, group identity and interpersonal identity. Face sensitivity, which is comprised of individual face and group face concerns, permeates every aspect of rapport management. It not only contains individuals' sense of being, dignity, identity, but also involves elements of respect, honor, status, reputation and competence. In intercultural communication, face needs involve individual face, group face as well as identity face when rapport is impaired. In this case, for individual face, $\mathrm{Li}$, with the knowledge that honesty is highly valued in the western culture and her integrity was still under suspicion, endeavored to defend herself even after she had achieved her goal for the signature. On the other hand, $\mathrm{Li}$, as one of the members of the intellectuals, a group of people who attach significant importance to reputation and face in Chinese tradition, would definitely defend her group face (integrity) when it was challenged. What's more, when her integrity was threatened, $\mathrm{Li}$, who was a college teacher, would undoubtedly try utmost to protect her identity face as teachers are highly respectable as a profession in the Chinese culture.

\subsubsection{Individual Factors}

Individual factors, mainly associated with emotion regulation competence and linguistic strategy competence, may also have an impact on rapport management.

\section{(1) Emotion Regulation Competence}

Emotion regulation competence is one of the key factors for rapport management, which enables people to be resilient to "handle criticism or embarrassment when things go wrong, and accept and feel at ease with people who are different" (ibid., 102). In Li's case, though Li could detect Ellen's annoyance, she did not employ the avoidance strategy with conflicts which is commonly used in Chinese culture (Friedman et al., 2006). Instead, she strove to communicate with Ellen and Susan to alleviate the threat brought by her rapport-threatening behaviors. Meanwhile, though Susan assumed that what Li had done undermined her autonomy rights and expressed irritation, she still offered an alternative for Li. To a certain extent, both $\mathrm{Li}$ and Ellen demonstrated the resilience in handling the difficult situation and showed a willingness to accept different behavioral expectations, which not only helped pacify the other interlocutor, but also helped themselves achieve their goals. Therefore, emotion regulation competence is of great significance to resolve conflicts and maintain rapport.

\section{(2) Linguistic Strategy Competence}

Linguistic strategy competence refers to the ability to adopt different language strategies in accordance to different orientation of rapport management in communication, including variety of expressions and stylistic flexibility. In Li's case, Susan first chose stylistically formal expressions, such as sentences of passive voice, subjunctive mood, imperative sentences, and non-subject sentences when the conflicts occurred, among which the longest one contained 37 words. The formality in style culminated in a sense of distance and alienation. However, the style changed from formal to informal with a very short sentence of three words after she received Li' email which aimed to eliminate the misunderstanding. The change in style indicated that Susan had a good command of linguistic strategy for different rapport management orientations. On the other hand, Li opted for syntactic and lexical mitigation in request emails but boosters when emphasizing her integrity, signaling that Li was also competent in adjusting linguistic strategies based on different interactional goals.

\section{CONCLUSION}

Rapport is the mutual demand for interlocutors in interpersonal communication when they are expected to take into consideration each interlocutor's face, rights, autonomy, cost-benefit and association. As key factors of rapport management, face sensitivity, behavioral expectations and rights 
and obligations, are greatly affected by various factors, including cultural, contextual and individual differences as they inevitably attribute to the different judgment of face, behavioral expectations and rights and obligations, which may initiate conflicts in the course of interpersonal communication.

Request, which is conventionally considered as a face-threatening act, is prone to threaten rapport management. This study, by demonstrating rapport management strategy in intercultural communication and exploring the impact of cultural, contextual and individual factors on rapport management, proposes that more focus should be given to the interaction of social, cognitive, cultural, contextual and individual factors on interpersonal relationship management, including speech act and sociopragmatic conventions in interpersonal communication as well as the relationship among communicators, power, distance, interactional content and social roles. What's more, it is necessary for future research to adopt a multidimensional perspective based on research on (im)politeness, intertexuality, relevance theory and traditional cultural anthropology, etc. in interpersonal communication research so as to provide a more comprehensive description of interpersonal communication and further elaborate the dynamics and complexity of rapport management.

\section{ACKNOWLEDGEMENT}

This work was supported by the innovative research funding of Guangdong University of Foreign Studies, China (No. 19SS14).

\section{REFERENCES}

[1] Beebe, L., T. Takahahsi\& R. Uliss-Weltz. Pragmatics transfer in ESL refusals[A]. In R. Seaarcella, E. S. Aderson\& S. Krashen (eds). Developing Communicative Competence in Second Language[C]. New York: Newbury House, 1990, 55-73.

[2] Bjorge, A. K. Power distance in English lingua franca e-mail communication[J]. International Journal of Applied Linguistics, 2007, 17(1): 60-81.

[3] Brown, G. \& S. C. Levinson. Politeness: Some Universals in Language Usage[M]. New York: Cambridge Press, 1987.

[4] Culpeper, J. Impoliteness:Using Language to Cause Offence[M]. London: CUP, 2009.

[5] Felix-Brasdefer, J. C. Interlanguage refusals: linguistic politeness and length of residence in the target community[J]. Language Learning, 2004, 54(4): 587-653.

[6] Fraser, B \& W. Nolan. The association of deference with linguistic form[A]. In J. Walters (eds.) The Sociolinguistics of Deference \& Politeness. Special Issue of International Journal of the Sociology of Language[C]. Hague: Mouton Publishers, 1981, 93-111.

[7] Friedman, R., S. C. Chi \& L. A. Liu. An Expectancy Model of Chinese-American Differences in ConflictAvoiding[J]. Journal of International Business Studies, 2006, 37(4): 572-573.

[8] Hall, E. T. The Silent Language[M]. New York: Anchor Books, 1990.

[9] Jensen, J. Discourse strategies in professional e-mail negotiation: A case study[J]. English for Specific Purpose, 2009(28): 4-18.

[10] Kasper, G. Linguistic etiquette[A]. In F. Coulmas (eds.). Handbook of Sociolinguistics[C]. Oxford: Blackwell, 1996, 374-385.

[11] Leech, G. N. Principle of Pragmatics[M]. London: Longman, 1983

[12] Spencer-Oatey, H. Rapport management: A framework for analysis[A]. In H. Spencer-Oatey (eds.). Culturally Speaking: Managing Rapport Through Talk Across Cultures[C]. London: Continuum, 2000, 11-46.

[13] Spencer-Oatey, H. \&Jiangyu Xing. A problematic Chinese business visit to Britain: Issue of face[A]. In H. Spencer-Oatey (eds.). Culturally Speaking: Managing Rapport Through Talk Across Cultures[C]. London: Continuum, 2000. 276-288.

[14] Spencer-Oatey, H. Managing rapport in talk: Using rapport sensitive incidents to explore the motivational concerns underlying the management of relations[J]. Journal of Pragmatics, 2002(34): 529-545.

[15] Spencer-Oatey, H. Rapport management theory and culture[J]. Intercultural Pragmatics, 2005, 2(3): 335-346.

[16] Spencer-Oatey, H. Face, (Impoliteness) and rapport[A]. In Spencer-Oatey, H. (eds.). Culturally Speaking: Culture, Communication and Politeness Theory[C]. London: Continnum, 2008, 11-47.

[17] Spencer-Oatey, H. \& P. Franklin. Intercultural Interaction: A Multidisciplinary Approach to Intercultural Communication[M]. Basingstoke: Palgrave Macmillan, 2009. 
[18] Swales, J. Genre Analysis: English in Academic and Research Settings[M]. Cambridge: CUP, 1990.

[19] Watts. J. Politeness[M]. Cambridge: CUP, 2003.

[20] Ran, Yongping. The Rapport Management Model and Its Violation in Interpersonal Interaction[J]. Foreign Language Education, 2012, 33(4): 1-5.

\section{AUTHORS'BIOGRAPHY}
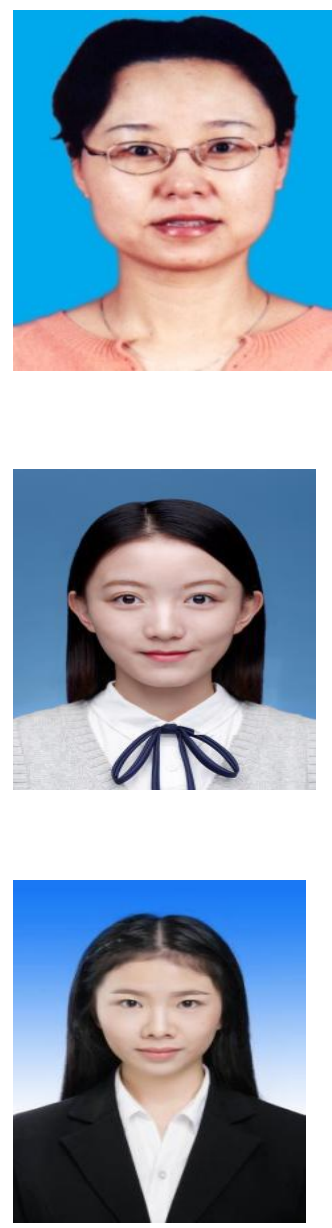

Wu Jihong is a professor of English at Guangdong University of Foreign Studies(Gdufs). She obtained her doctor degree in Applied Linguistics at Gdufs in 2010. Her areas of research include Cognitive Linguistics, Lexicography, BELF research and English teaching. She is the author of many publications, including A Cognitive Approach to the Lexicographic Representation of Collocations in English-Chinese Learners' Dictionaries (2011), Retrospection and Expectation: A Review on Studies of China English (2016), and BELF: A New Research Paradigm for Intercultural Business Communication (2017).

Ziqing HUANG (1995- ) is a postgraduate student in Guangdong University of Foreign Studies, China. Her academic interest is mainly business discourse analysis.

Min LIU (1994- ) is a postgraduate student in Guangdong University of Foreign Studies, China. Her academic interest is on BELF (English as a business lingua franca) and pragmatics.

Citation: Wu Jihong, et.al., "Rapport Management in Intercultural Interaction-A Case Study on Emails" "International Journal on Studies in English Language and Literature (IJSELL), vol 8, no. 3, 2020, pp. 6-16. doi: http://dx.doi.org/10.20431/2347-3134.0803002.

Copyright: (C) 2020 Authors. This is an open-access article distributed under the terms of the Creative Commons Attribution License, which permits unrestricted use, distribution, and reproduction in any medium, provided the original author and source are credited. 